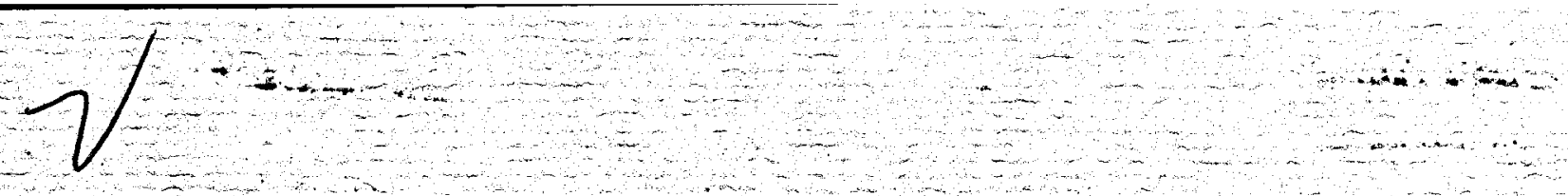

\title{
NATIONAL GEOTHERMAL TEST FACILITY
}

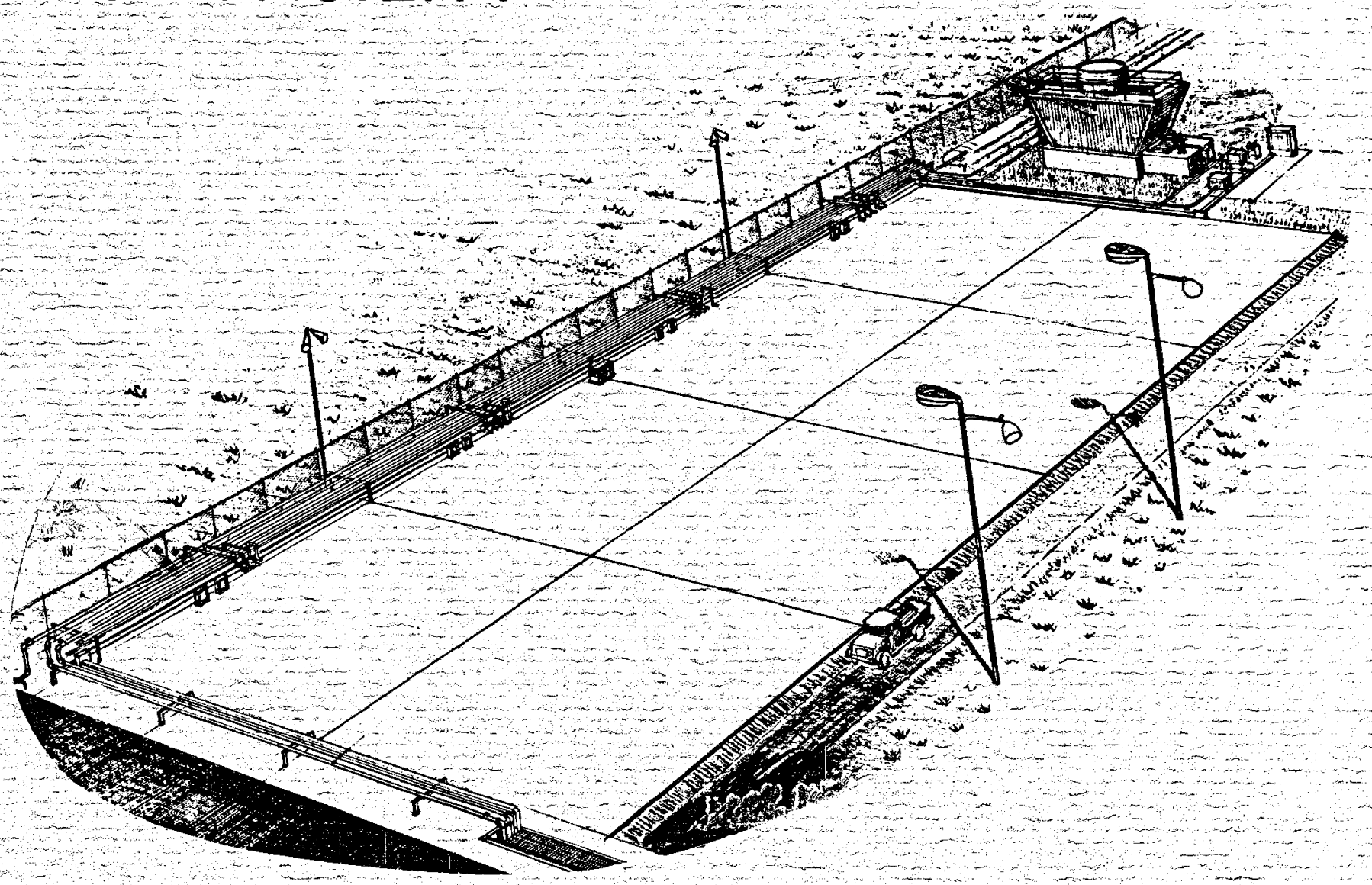

EAST MESA, IMPERIAL VALLEY, CALIFORNIA

\section{MASTER}

DISTRIBUTION OF THIS OUCUMENT IS UNLIMITED 


\section{DISCLAIMER}

This report was prepared as an account of work sponsored by an agency of the United States Government. Neither the United States Government nor any agency Thereof, nor any of their employees, makes any warranty, express or implied, or assumes any legal liability or responsibility for the accuracy, completeness, or usefulness of any information, apparatus, product, or process disclosed, or represents that its use would not infringe privately owned rights. Reference herein to any specific commercial product, process, or service by trade name, trademark, manufacturer, or otherwise does not necessarily constitute or imply its endorsement, recommendation, or favoring by the United States Government or any agency thereof. The views and opinions of authors expressed herein do not necessarily state or reflect those of the United States Government or any agency thereof. 


\section{DISCLAIMER}

Portions of this document may be illegible in electronic image products. Images are produced from the best available original document. 
Lawrence Berkeley Laboratory

University of California

Berkeley, Cal ifornia 94720

Operated for U.S. Energy Research and Development

Administration under Contract W-7405-ENG-48

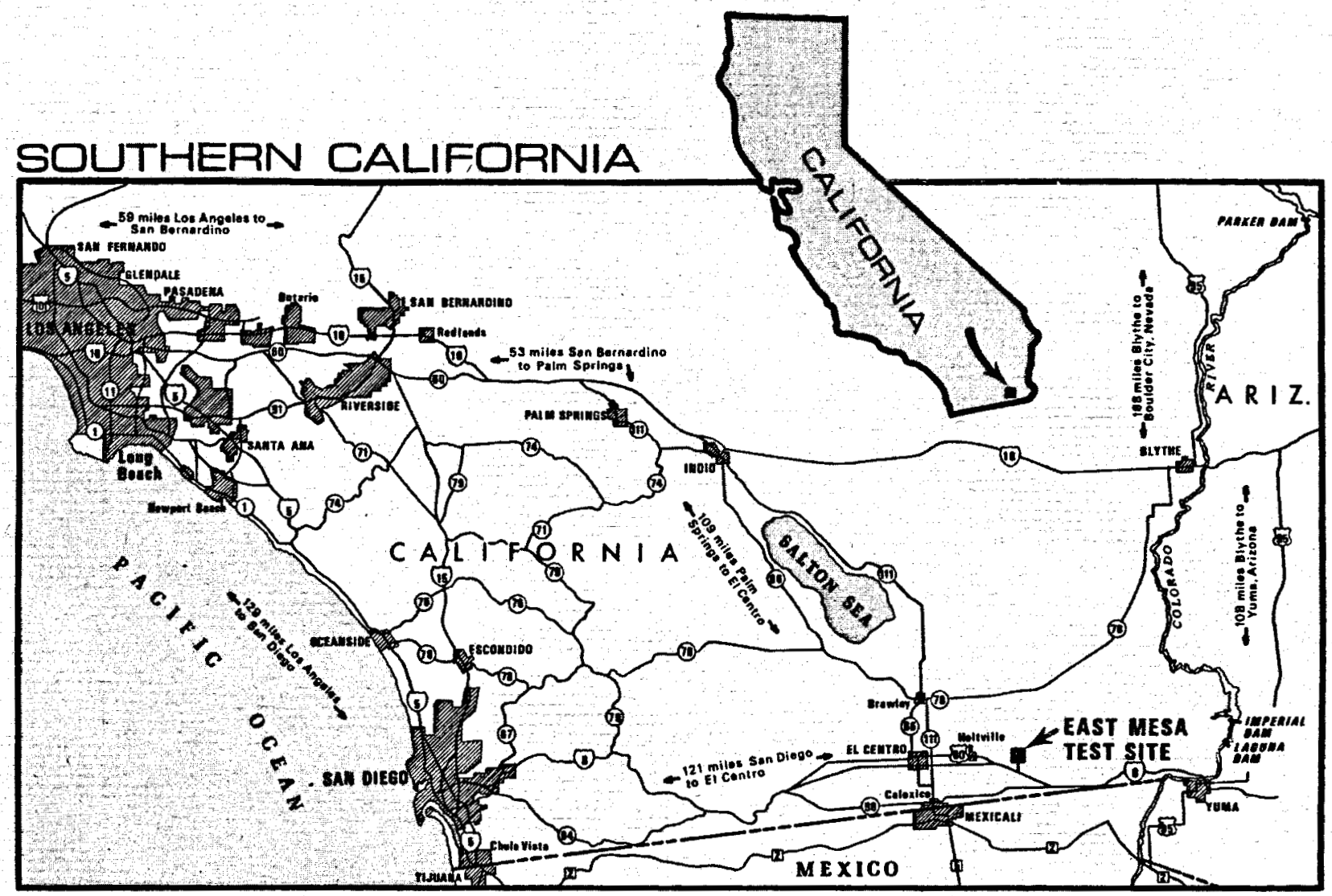

Figure 1. Location of the East Mesa Test Site. (Courtesy U.S. Department of Interior, Bureau of Reclamation).

COVER: Perspective of East Mesa

Geothermal Test Facility - test pad area, piping, and cooling equipment. 


\section{NATIONAL GEOTHERMAL TEST FACILITY}

Geothermal energy, derived from the natural heat in the Earth's crust, has the potential for contributing significantly to U.S. energy needs within the next 25 years. This very large resource consists either of steam, hot water, hot rock, magma, or normal earth-heat gradients. However, several recent studies agree that "1iquid-dominated" geothermal systems - hot water containing dissolved salts, and maybe some steam - could be the largest electricity-producing geothermal resource by 1985 if a concerted assault is made on the technical problems, and that these hot brines could generate tens of thousands of megawatts (electrical) by the year 2000 .

\section{Liquid-dominated geotherma1} sources vary considerably in their temperature and salt content. The most usable, according to a study by the Electric Power Research Institute, are those brines with a high temperature (greater than $180^{\circ} \mathrm{C}$ ) and low salinity (1ess than 20,000 parts per million total dissolved solids). The study concludes that this resource could provide about $50 \%$ of the U.S. geothermal electrical production by 1985.

The potential size of the hotwater geothermal resource and its possible early utilization have motivated the Energy Research and Development Administration (ERDA) to establish the first National Geothermal Test Facility at East Mesa near E1 Centro in the Imperial Valley of California (Fig. 1). The Facility will enable industry and government scientists to obtain data relevant to the technical problems that must be solved before these hot brines can contribute to U.S. electrical production.

HISTORY OF THE EAST MESA TEST SITE

Since 1971, the geothermal reservoir underlying the East Mesa Test Site has been under development by the Bureau of Reclamation, U. S. Department of the Interior, for a water-desalting demonstration plant. In this work, the Bureau has made extensive studies of the reservoir and has drilled four producing test wells and one injection well (Fig. 2); it also has assembled support services and constructed surface plumbing, a brine-holding pond, desalting test installations, and a warehouse.

Although these facilities are being used as a field laboratory for desalting studies, the brines from the wells are also suitable for other purposes; in particular, the Site 


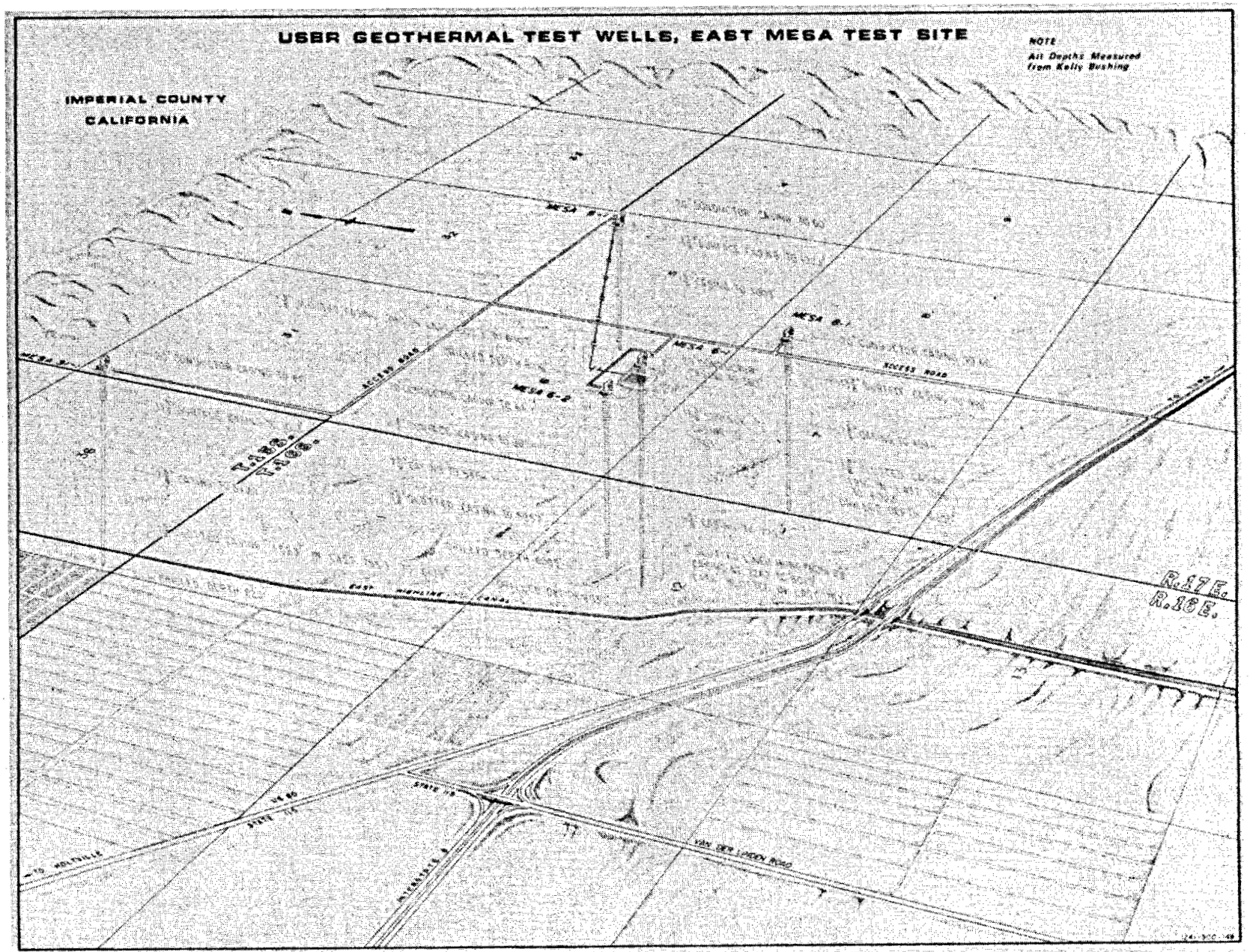

Figure 2. Phantom view of East Mesa geothermal we11s.

provides an ideal setting for testing various types of geothermal energyconversion equipment and materials under field conditions using actual geothermal fluids. Thus in May 1975 ERDA agreed to fund a $\$ 1,040,000$ geothermal test facility, to be built by the Bureau of Reclamation, that could be used by public, private, and academic scientists as a field 1aboratory.

Lawrence Berkeley Laboratory, an ERDA National Laboratory, was assigned the task of directing the design effort that is being carried out by the Bureau of Reclamation. Further, LBL was placed in charge of formulating the initial experimental program.

DESCRIPTION OF THE TEST FACILITY

The National Geothermal Test Facility, now under construction at the East Mesa Test Site, is expected to be in operation by August 1976. It will be supplied by brines from three of the already existing production 
wells, each brine having distinctive physical characteristics (Table I).

Plans are under consideration to insta11 downhole pumps in the Mesa 6-1 and Mesa 8-1 wells; this equipment will boost the brine pressures so that higher flow rates will be possible without having the brine flash to steam in the wel1. Providing unflashed brine will also permit the wellhead brine temperatures to approach the bottomhole temperatures. Spent brines from the Test Facility. will be put back into the reservoir through the Bureau of Reclamation's reinjection well (Mesa 5-1). The existing holding pond provides for temporary overflow or bypass conditions.

Geothermal tests and experiments will be set up at various locations on a large concrete test pad, 80 feet by 160 feet. Four manifold locations serve the pad, providing brine supply and return, cooling tower water supply and return, domestic water, blow-down to the holding pond, and compressed air. Electrical supply at the Test Site has a $375 \mathrm{kVA}$ capacity, while at the test pad itself $480 / 208$ volts $A C$ three-phase and 120 volts AC single phase are available. The cooling tower for the Test Facility has a heat rejection capacity of 5 megawatts, with provision for expansion to 10 megawatts when needed.

The Test Site includes offices and a chemistry 1aboratory, as wel1 as a complete machine shop for repair, maintenance, and assembly work (Fig. 3). The laboratory will be designed for carrying out routine analyses of brines and deposits. Details of the operating arrangements are not yet final and may be modified as conditions change; but as presently planned, experimenters will be able to use the test pad facilities without charge. Labor needed on the test pad also will be provided without

TABLE I. Brine characteristics.

\begin{tabular}{|c|c|c|c|c|c|}
\hline We11 & $\begin{array}{l}\text { Bottom hole } \\
\text { temperature } \\
\left({ }^{\circ} \mathrm{C}\right)\end{array}$ & $\begin{array}{l}\text { Wellhead bri1 } \\
\text { temperature } \\
\left({ }^{\circ} \mathrm{C}\right)\end{array}$ & ine & $\begin{array}{c}\text { Maximum } \\
\text { natural } \\
\text { flow } \\
(1 \mathrm{~b} / \mathrm{hr})\end{array}$ & $\begin{array}{c}\text { Total } \\
\text { dissolved } \\
\text { solids (ppm) }\end{array}$ \\
\hline Mesa 6-1 & 200 & 130 & at & 211,000 & 25,000 \\
\hline Mesa 6-2 & 188 & 134 & at & 150,000 & 2,500 \\
\hline Mesa 8-1 & 179 & 127 & at & 184,000 & 2,500 \\
\hline
\end{tabular}




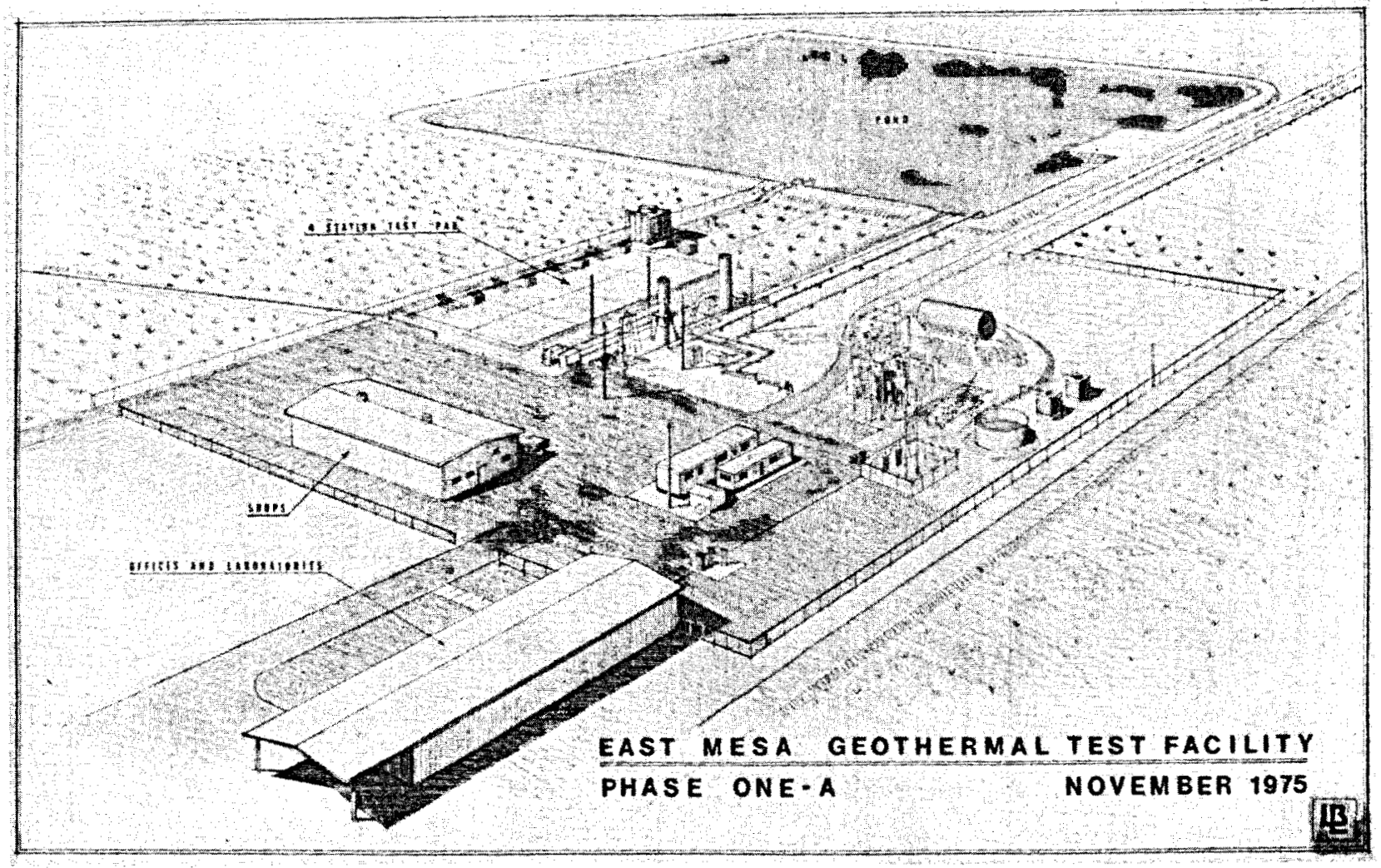

Figure 3. Perspective of the East Mesa Site.

charge, except for those users wishing to keep their test results proprietary. Use of the machine shop, chemistry laboratory, and office space will be provided at cost.

\section{EXPERIMENTAL PROGRAMS}

Geothermal brines can be used not only to produce electricity but also to accomplish various tasks in industry and agriculture; both the electric and the non-electric applications use much the same basic equipment. To develop these uses, technological improvements are needed in the following areas:
- Prevention of erosion, corrosion, and scale deposition in pipelines, pumps, and process equipment (Fig. 4).

- Increased efficiencies of conversion for various power cycles.

- Improved equipment for use in direct contact with geothermal brines.

- Development of direct-use processes, such as might be used in wood-pulp plants and in agricultural processes. 


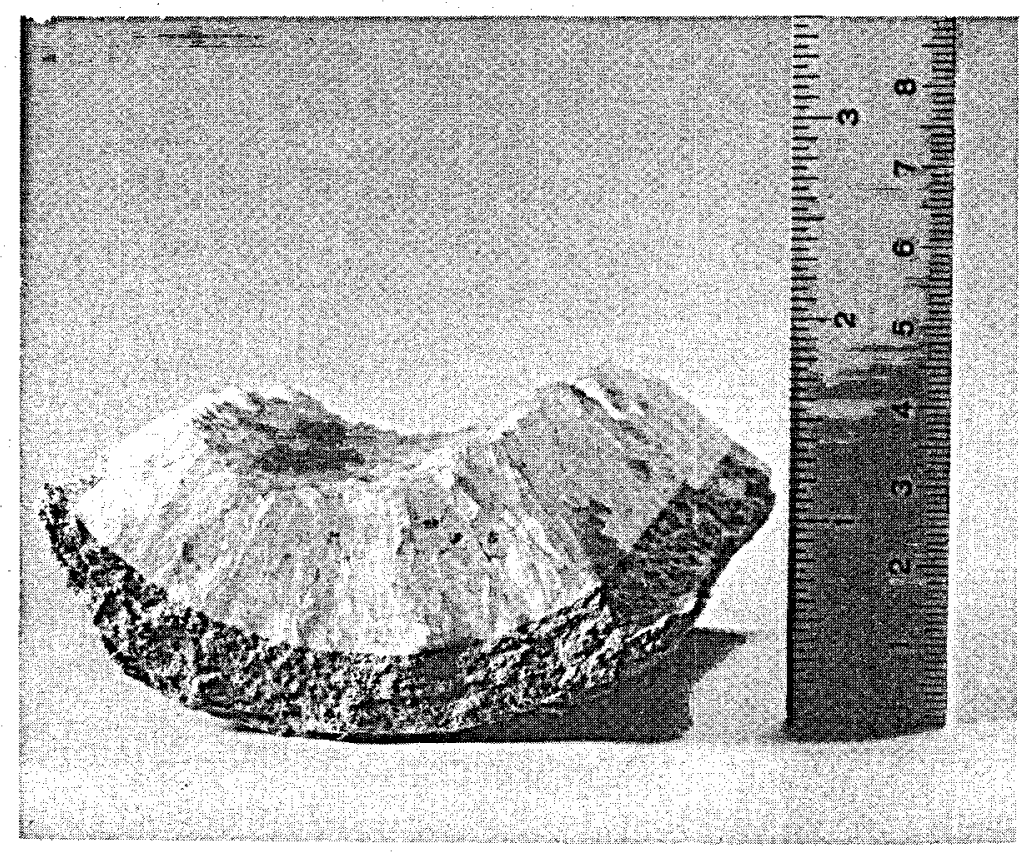

Figure 4. Calcium carbonate scale deposited in a transite pipe by a geothermal brine in the Raft River region of Idaho.

\section{Heat Exchangers}

A high-priority activity in geotherma1-energy application is the development and testing of brine heat exchangers. Emphasis in this area will be on solving the critical problem of scale formation (usually calcium carbonate and silica) on heat exchanger surfaces and developing reliable heat-transfer data.

A number of possible ways to control deposition could be investigated at the National Geothermal Test Facility, including the use of scale inhibitors, ion exchange, and precipitation accelerators; these tests to find out how and why coatings form on pipes and equipment require a continuous supply of fresh brine over a long period of time. Actual geothermal brines are also needed to check laboratory data on the chemistry and thermodynamics of brines, since the results of measurements often depend on the presence of trace elements in the brine. Improved data will make it possible to design heat exchangers with confidence.

Eventually, the problems of heatexchange with geothermal brines may be resolved by use of innovative types of heat exchangers such as fluidized beds or direct contact configurations. The Test Facility will provide brines, 
cooling water, and work space for evaluating these altematives as they are developed.

Power Cycles

Although several energy conversion systems (power cycles), and combinations of systems, have been suggested for exploiting geothermal brines, only the single-flash system has been thoroughly tested under field conditions. Few conclusions can be reached concerning relative operating economies of these various proposed systems until assumed values of operating parameters are verified by realistic experiments. Alternate systems that hold promise, and which should be tested, are the following:

- Binary fluid cycles. Potential binary fluids, such as isobutane and ammonia, will be evaluated to determine optimum operating ranges for pressure, temperature, and flow rate (Fig. 5). A binary cycle, operating at geothermal temperatures which are lower than those in fossil fuel or nuclear plants, is necessarily less efficient. Improvements in geotherma1 power cycles so that they perform closer to the Camot efficiency limit will provide for more efficient resource utilization, better use of capital investment, and less generation of waste heat.

- Two-phase expansion cycles (Total Flow Concept). Because this system probably will require a direct-contact condenser (where brine and cooling water actually meet), scaling and corrosion are likely to be severe in both the condenser and the cooling tower. Studies at the Test Facility of scaling, corrosion, cycle efficiencies, and noncondensable gas disposal will provide the materials, component, and process data needed to explore this approach to using geothermal energy.

- Combination cycles. Suggestions for combining binary and steam-flash cycles into one system are numerous; as these new cycles and components are developed, the Test Facility will be available and adequate for detailed testing of their performance under realistic field conditions.

\section{Brine Delivery and Reinjection} Systems

Another problem area that can profitably be examined at the Test Facility is we11 technology, such as casings, delivery pumps, and reinjection systems. Brine-treatment processes also may be studied, since it 


\section{HIGH TEMPERATURE-LOW SALINITY FIELD TEST FACILITY Binary Cycle Test}
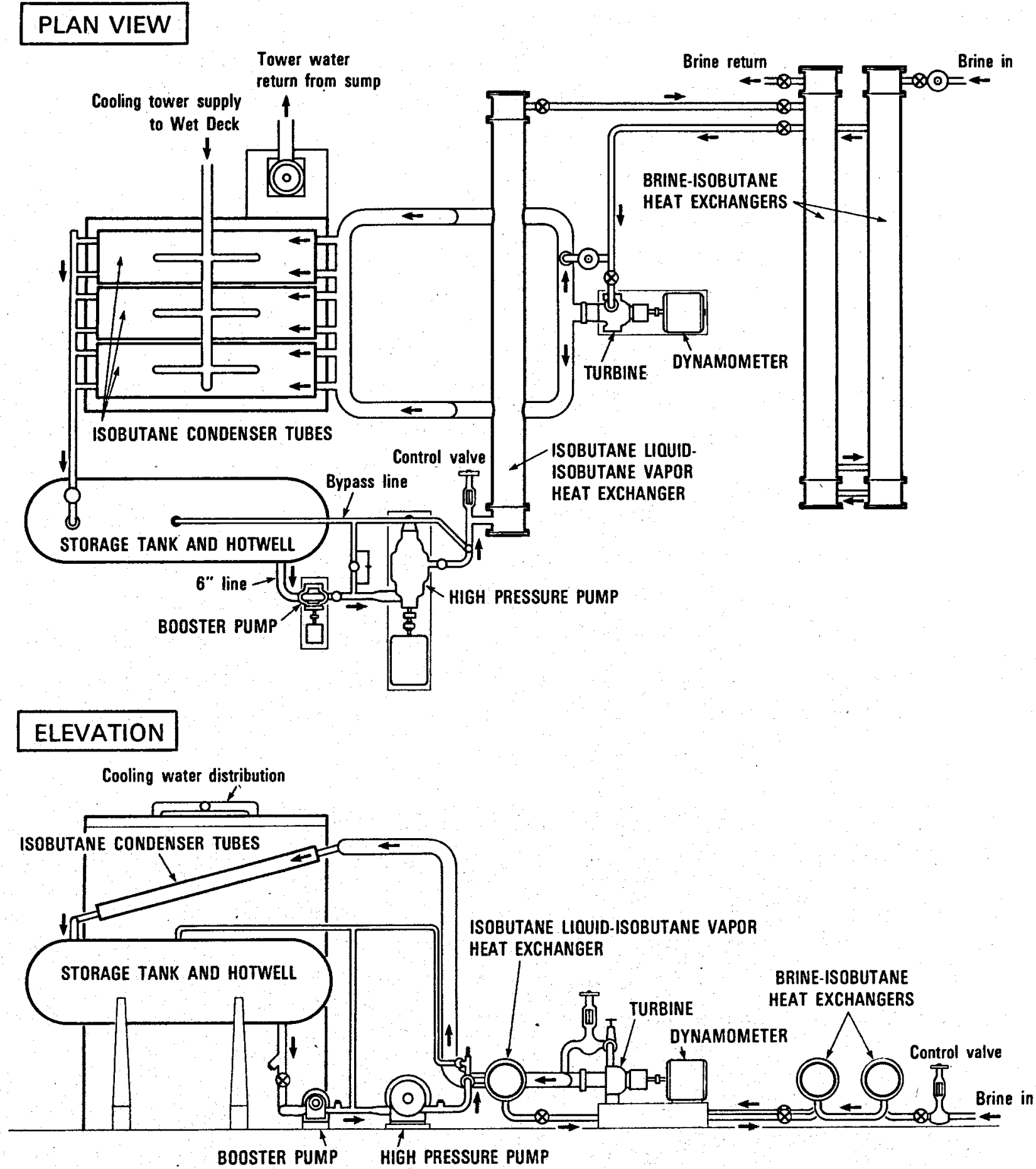

Figure 5. Proposed arrangement of equipment for a binary test suitable for generating electricity. 
has been observed that the rate of reabsorption of brines decreases as the pores in the rock surrounding the reinjection well become plugged with minerals. Various treatments of the brine are possible to decrease its interaction with rock formations; these need to be evaluated to see if any can appreciably extend the lifetime of reinjection we11s.

Direct-Use Processes

Geothermal energy in its natural state is simply heat. Any residential, commercial, or industrial process requiring heat is a candidate for utilization of this a1ternative energy source. Possible areas of application - other than for generating electricity, which may become a major use are for hydroponics, fish-farming, growing greenhouse crops, de-icing highways, heating buildings, manufacturing paper pulp, and drying timber and produce. Because these applications make direct use of geothermal heat, they do not incur the losses of efficiency that result when energy has to be transformed and transported.

FUTURE OF THE TEST FACILITY

Further development of the Test Facility is planned. Included in these plans are additional we1ls, expansion of the test pad and increased cooling capacity to permit larger-scale experiments.

When the present construction work is completed, the National Geothermal Test Facility at East Mesa will be able to provide industry with a convenient and inexpensive means for testing prototype processes.

Engineers and manufacturers of . equipment interested in using the Test Facility, or in finding out more about it, should contact Eric Festin, Facilities Coordinator, Lawrence Berkeley Laboratory, Berkeley, California 94720. Telephone: (415)843-2740, ext.5036. 